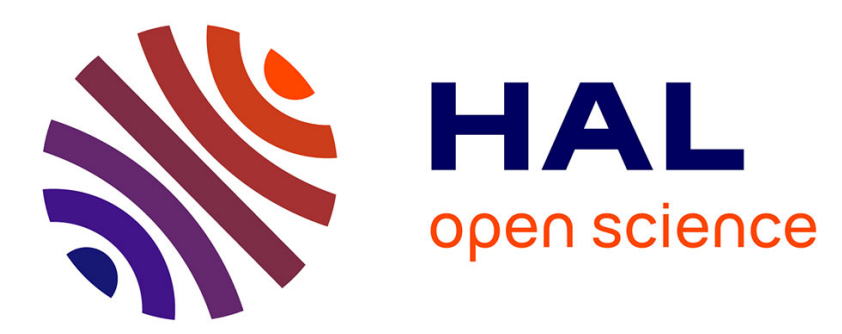

\title{
A Resource Based Interpretation of Performance Enhancing Capital Structure Changes: The O.M. Scott LBO Revisited
}

Peter Wirtz

\section{- To cite this version: \\ Peter Wirtz. A Resource Based Interpretation of Performance Enhancing Capital Structure Changes: The O.M. Scott LBO Revisited. FMA European Conference (Financial Management Association), Jun 2005, Siena, Italy, Italy. halshs-00746277}

\section{HAL Id: halshs-00746277 \\ https://shs.hal.science/halshs-00746277}

Submitted on 28 Oct 2012

HAL is a multi-disciplinary open access archive for the deposit and dissemination of scientific research documents, whether they are published or not. The documents may come from teaching and research institutions in France or abroad, or from public or private research centers.
L'archive ouverte pluridisciplinaire HAL, est destinée au dépôt et à la diffusion de documents scientifiques de niveau recherche, publiés ou non, émanant des établissements d'enseignement et de recherche français ou étrangers, des laboratoires publics ou privés. 


\title{
A resource based interpretation of performance enhancing capital structure changes: The O.M. Scott LBO revisited
}

Peter Wirtz Université Lumière (Lyon 2)

\begin{abstract}
The O.M. Scott case study published in 1989 in the Journal of Financial Economics has come to be a classic in illustrating the plausibility of some fundamental concepts that underpin mainstream models of the efficiency attributes of capital structure in modern corporate finance. In these models, high leverage traditionally appears as a strong incentive to refrain from sub-optimal investment behavior by self-interested managers. Thus reducing managerial agency cost has been considered as an essential driver of enhanced value in much of financial modeling. In the present paper, we attempt a somewhat different, albeit complementary, mainly resource based interpretation of the very rich empirical material contained in Baker and Wruck (1989). In fact, a close reading of the case suggests that the observed significant increase in operating performance post-LBO was to a great extent the consequence of the yet unexplored cognitive changes implied by switching dominant shareholders. Namely, we find that value at O.M. Scott was essentially increased by (1) a significant reduction in what may be termed cognitive agency costs while (2) the new dominant shareholder contributed substantial cognitive value by stimulating and advising a dynamic learning process leading to enforced managerial capabilities, especially with respect to more effective routines of cash management.
\end{abstract}

Key words $\cdot$ capital structure $\cdot$ cognitive agency costs $\cdot$ cognitive value $\cdot$ managerial agency costs 
In a well documented case study published in 1989 in the Journal of Financial Economics, Baker and Wruck described the case of the leveraged buyout of the O.M. Scott and Sons Company and the resulting substantial increase in operating performance. The analytic focus of their article may be described as an effort to apply the conceptual tool box of traditional positive agency theory (Jensen and Meckling, 1976; Jensen, 1986) to establish a plausible link between the incentive structure resulting from an increase in leverage and enhanced firm value. In an attempt to fully understand the nature and behavioral influence of incentives, Baker and Wruck achieved an in-depth analysis of the underlying (contractual) mechanisms. In doing so, the authors not only confirmed some of PAT's (positive agency theory's) most fundamental reasoning, but also helped to put some flesh on the bones of the theoretical structure of one of the most prominent approaches modern corporate finance has to propose to come to grips with the classical capital structure puzzle raised by Modigliani and Miller (1958).

While we basically agree with the major conclusions concerning the positive impact of the LBO's incentive structure on long-term value creation by imposing constraints on management limiting the possibilities of sub-optimal myopic behavior, we contend that there is more to it than merely financial discipline. Especially, a close reading of the O.M. Scott case raises the central question of where the superior value creation capability actually came from in the first place, rather than of how to simply reduce managerial agency costs of conflicting interests in the traditional sense (Berle and Means, 1932). In fact, one of the shortcomings of traditional agency theory's financial modeling, when considered in its most rudimentary form, lies in its assuming opportunities for value creation to be given with objectively communicable performance parameters ${ }^{1}$ (Jensen, 1986) ${ }^{2}$. In doing so, the financial models gain analytical sharpness. Narrowly focusing on problems of agency costs allows for parsimonious explanations of efficient capital structure changes in situations where improper alignment of incentives and failure in systems of control actually exist. However, reducing 
agency costs is but one possible, albeit potentially relevant, dimension along which to proceed in an effort to enhance value.

With a longstanding tradition in strategy research, the resource based approach of the firm as pioneered by Penrose (1959) takes on a different perspective. In doing so, it allows for a genuine understanding of some significant sources of value which are neglected by traditional PAT. Hence we hold that to fully understand the enhanced operating performance post-LBO it is useful to complement the rather narrow agency theory explanation contained in Baker and Wruck with resource based arguments, especially with respect to managerial cognition of productive opportunities (Barney, 1986) and the existence and development of firm-specific organizational capabilities (Teece, Pisano and Shuen, 1997; Winter, 2000).

In the present paper, we will argue that the O.M. Scott case as reported in Baker and Wruck (1989) actually contains some yet under-exploited empirical facts consistent with a resource based perspective on changes in capital structure. Notably, we establish that, beside the incentives of high leverage, the change of dominant shareholders brought about by the LBO (1) reduced value destroying cognitive cost by conferring more "coordination control" ${ }^{3 \text { " over }}$ internally generated resources on incumbent management and (2) simultaneously stimulated a learning process allowing for the dynamic adaptation of organizational capabilities (e.g. more efficient management of working capital by changed routines of production) to perceived changes of the firm's environment ${ }^{4}$.

The paper is structured as follows. In the first section, we briefly recall the principal events of the O.M. Scott case as well as the main conclusions drawn by Baker and Wruck. In the second section, the major shortcomings of traditional capital structure analysis as well as one possible way of pushing our understanding further will be discussed. Sections three and four highlight and reinterpret some of the empirical evidence contained in the O.M. Scott case concerning respectively the impact of varying degrees of cognitive cost and of learning new organizational capabilities. Section five concludes insisting on the complementary 
contributions of PAT and resource based theory to the understanding of the performance impact of capital structure changes.

\section{Principal Events around the O.M. Scott LBO}

The following is a brief summary of the most salient events as reported in Baker and Wruck (1989). At the time of the leveraged buyout, O.M. Scott was the largest producer of lawn care products in the United States. The company started off at the end of the nineteenth century as a specialist in the sale of farm crop seed, but reconverted itself at the beginning of the twentieth century when it commercialized weed-free lawn seed through the mail. In the nineteen-twenties, Scott came up with a series of product innovations, making it a first mover with respect to several new products which completed the range of the lawn market offer. With respect to capital structure, it should be noted that Scott began as a family business and was closely held for almost a century. A major change in capital structure came about in 1971, when $100 \%$ of its stock was purchased by ITT, a widely diversified conglomerate.

During the period of the conglomerate's exclusive control, O.M. Scott management experienced significant restrictions with respect to capital resources. Internal funding was almost unavailable. In fact, the entire cash flow generated by the home lawn specialist was immediately transferred and brought under the conglomerate headquarters' control. The latter attributed financial resources only as a function of a bureaucratically controlled and relatively rigid budget. In fact, Baker and Wruck (1989) state that the ITT control system "did not give [Scott's] managers the flexibility [...] to use their specialized knowledge of the business [...]" (p. 177) Lacking access to internal finance, Scott management was often unable to make the necessary investments to respond to its expert view of changed market conditions. Actually, at a certain point of time, "Scott managers found their requests for capital funds were routinely 
denied." (p. 184) They were thus strongly limited in their possibility to develop the business, in the way they perceived as being "optimal".

This frustration with being unable to deploy a strategy they felt was best suited to enhance Scott's development may explain one early attempt made by incumbent managers to become themselves the controlling shareholders. Several years before the actual LBO realized in 1986 by Clayton and Dubilier, O.M. Scott managers tried to directly negotiate a management buyout with ITT (p. 173). But, at that time, the proposal did not match with ITT's own corporate objectives. It was seen as posing a conflict of interest.

Major change came in early 1985, when ITT, confronted with declining performance, found that to enhance efficiency it would be necessary to become a specialist of only a few businesses and thus to sell off assets that did not correspond to what was henceforth considered to be its specialties (telecommunications, insurance, high technology). Scott appeared on the list of companies to be divested. At that time, the controlling shareholder's (ITT's) interest changed from exerting ongoing (coordination) control over cash flow generated by Scott to simply selling off the company to the highest bidder. The latter happened to be a specialist in the business of leveraged buyouts, Clayton and Dubilier (C\&D), who became the new dominant shareholder by virtue of an LBO realized in December 1986. The transaction was essentially financed by debt, leaving Scott with a financial structure of only 9\% equity (p. 165). The latter was essentially controlled by C\&D with a large majority of $61.4 \%^{5}$. The high degree of leverage imposed minimal cash flow requirements, forcing Scott to develop skills of more efficient cash management. But it is worth noting that, in spite of the existence of debt covenants, management's discretion over the use of internally generated funds eventually in excess of the requirements of the debt repayment schedule found itself actually enlarged as a result of the special relationship with the new dominant shareholder. In fact, under C\&D's ownership control, the incumbent management was granted greater autonomy than under ITT to invest in the activities it felt best suited to assure the 
company's future development. That is to say, C\&D highly valued the incumbent management's specific expertise.

If $C \& D$ was able to put in the highest bid for the acquisition of shares, this is most probably due to this actor perceiving the highest value creation potential in O.M. Scott compared to the other candidates for becoming controlling shareholders ${ }^{6}$. This a priori perception seems consistent with Baker and Wruck's (1989) observation of a significant actual increase in operating performance post LBO. The authors contend that, in this case, improved performance can be explained in a satisfactory manner by traditional PAT-reasoning. They "interpret their results as being consistent with an agency theory of the firm in which high leverage and managerial equity ownership lead to improved incentives and consequently improved operating performance." (p. 166, 167) Note that this traditional interpretation's emphasis lies on incentive alignment by granting an equity share to management (Jensen and Meckling, 1976) and on discipline by imposing constraints on managerial discretion through imposing a rigid debt repayment schedule (Jensen, 1986; Stulz, 1990). O.M. Scott's postLBO capital structure is thus seen as enhancing value by reducing agency costs in essentially two ways. Management's equity share tends to align pursuit of personal interest by managers with shareholder interest. However, interest alignment of this sort remains imperfect and is thus further enhanced by the burden of high leverage which acts as a limit on free cash flow available for sub-optimal investment (Baker and Wruck, 1989, p. 172). In a way consistent with a later study by Stulz (1990), Baker and Wruck (1989) recognize however that not having enough cash flow can also be a problem in that it prevents management from undertaking all potentially available positive NPV projects. Consequently, the authors argue that this potential cause of underinvestment has been resolved in the Scott case by the very nature of the debt covenants which assure the availability of just enough internal funding while simultaneously cutting down excess cash flow. In the authors' own words "the company's high leverage combined with covenants and management equity ownership 
provided managers with the incentive to generate the cash required to meet the debt payments without bleeding the company." (p. 175, 176, emphasis added)

\section{Major Shortcomings of Explanations Drawn from Traditional Capital Structure Analysis}

What is rather striking in Baker and Wruck's (1989) interpretation of their empirical material is the fact that the specific (cognitive) role of the new dominant shareholder, in this case the private equity firm, is not well explored. This may be explained in terms of traditional agency theory's almost exclusive analytical focus on the widely held managerial firm (Berle and Means, 1932), where costs due to the pursuit of managerial self-interest are potentially pervasive $^{7}$. In such a context, substantial gains may be expected by discipline and incentives leading to a decrease in agency costs in a traditional sense ${ }^{8}$. The relevance of mainstream explanations of capital structure thus really depends on the significance of managerial agency costs. However, the latter is most likely to be strongly reduced under a controlling dominant shareholder. In other words, ways of limiting managerial agency costs in the traditional sense may only significantly contribute to enhance value, where those problems are the main source of inefficiency in the first place. O.M. Scott never having been a managerial firm stricto sensu $u^{9}$, there may be some doubt concerning an explanation where the decrease in managerial agency costs, albeit present, is the only or even the most important driver of value.

In fact, a close reading of the O.M. Scott case suggests that we can gain further insight by analyzing this specific LBO-transaction not so much in terms of reducing agency costs, but rather in terms of "transaction value". According to the latter approach, "a wide variety of formal interorganizational arrangements is more a function of anticipated value gains, rather than anticipated losses due to the cost of constraining opportunism." (Zajac and Olsen, 1993, p. 132) 
A major difficulty of mainstream capital structure analysis in coming to grips with the creation of value is its supposing the range of possible value gains to be given, very much like a menu from which to choose. In fact, only to the extent that all possible positive NPV projects are known is the notion of free cash flow with the related managerial agency costs (Jensen, 1986) relevant. The problem of value then becomes one of discipline only. This mainly disciplinary perspective widely ignores the significant role of special productive skills as a distinct source of value. Even in those contributions to PAT where specific knowledge features explicitly (Jensen and Meckling, 1992), the analytical focus is on monitoring as well as reward and punishment and, thus, on discipline rather than on the distinct role of competence.

Because in a real-world setting the development of cognition and related capabilities follows path-dependent learning processes (Tripsas and Gavetti, 2000), certain productive skills are highly idiosyncratic and cannot easily be communicated. Consequently, one important problem to solve in an effort to better understand the creation of value likely concerns cognitive asymmetry linked to the construction of yet unrecognized productive opportunities and the possession of special productive skills necessary to exploit these opportunities. Cognitive asymmetry pertaining to methods of efficiently coordinating production activities is however distinct in nature from what promoters of agency theory commonly have in mind when they speak of asymmetric information ${ }^{10}$. Thus, traditional PAT seems insufficiently equipped to come to grips with enhanced performance in terms of the special productivity furnished by the specific knowledge and skill base of a closely cooperating (management) team. In fact, while a case was made for special productivity of this sort in Alchian and Demsetz (1972), one very important predecessor of agency theory, its sources were not explicitly discussed (Demsetz, 1988, p. 152). Interestingly, Demsetz's later attempt to explore deeper into these sources of superior performance brought him very close to a Penrosian and resource based perspective. Consider the following extracts. 
"Productivity may be affected by considerations that are not plausibly included in these [agency ${ }^{11}$ cost categories. Each firm is a bundle of commitments to technology, personnel, and methods, all contained and constrained by an insulating layer of information that is specific to the firm, and this bundle cannot be altered or imitated easily or quickly." (Demsetz, 1988, p. 148)

The cognitive dimension of enhanced performance and the conceptual proximity with Penrose (1959) becomes even clearer in the following:

"Particularly important in determining [...] benefits are knowledge-based considerations. Continuing association of the same persons makes it easier for firm-specific and person-specific information to be accumulated [...]. Knowledge about the objectives and organization of the firm is learned 'cheaply' through continuing association, and so is knowledge about the capabilities and limitations of the persons involved in this association." (Demsetz, 1988, p. 160)

More recently, in an attempt to overcome the limits of mainstream theories of corporate finance $^{12}$ in explaining the efficiency attributes of different configurations of capital structure, Charreaux (2002) proposed to integrate agency theory and a more cognitive approach, essentially inspired by evolutionary economics (Alchian, 1950; Nelson and Winter, 1982) and research in strategic management of the resource based and organizational capabilities kind (Penrose, 1959; Wernerfelt, 1984; Barney, 1986; Teece, Pisano and Shuen, 1997). He did so by introducing a new conceptual distinction between different types of agency costs and by adding the concept of "cognitive value" to PAT-reasoning. In his model, $\mathrm{A}_{\mathrm{MI}}$ (informational managerial agency cost) denotes agency costs in the traditional sense, that is to say due to the pursuit of objectively conflicting interests being made possible by asymmetric information when capital is widely dispersed. Informational agency costs also exist when shareholdings are closely controlled, but are likely to be less significant in that case. Their extent possibly depends on the characteristics of the dominant shareholder, especially with respect to his competence in controlling asymmetric information. There may, for example, be a difference in the intensity of informational agency costs between a firm having an industrial corporation as dominant shareholder $\left(\mathrm{A}_{\mathrm{MI}}^{\mathrm{IND}}\right)$ and another one being controlled by institutional 
investors $\left(\mathrm{A}_{\mathrm{MI}}^{\mathrm{II}}\right)$. So much for the traditional agency costs. Charreaux (2002) then introduced the concept of cognitive agency costs $\left(\mathrm{A}_{\mathrm{MC}}\right)$. These result from diverging perceptions between management and shareholders as to the best opportunities for the creation of value. Such divergence is rooted in incongruent mental patterns ${ }^{13}$ and is likely to occur in a real-world setting where uncertainty is pervasive and new opportunities for the creation of value can sometimes be endogenously constructed by management itself ${ }^{14}$. In this context, $\mathrm{A}_{\mathrm{MC}}$ can be understood as an opportunity cost of management not being able to pursue a value creation strategy it subjectively perceives as "optimal". This is most likely to be the case when owners do not understand management's arguments (due to fundamentally different cognitive structures $)^{15}$ while exerting strong control. Hence $\mathrm{A}_{\mathrm{MC}}$ should be more pervasive under certain dominant shareholders than when capital is widely dispersed. On the other hand, a new dominant shareholder may contribute valuable knowledge assets in the form of specific capabilities (e.g. C\&D's financial expertise with respect to cash management) which potentially make a significant contribution to the firm's ability to create value ${ }^{16}$. Charreaux (2002) referred to these as sources of cognitive value $\left(V_{C}\right)$. He then developed a formal model which demonstrates the fashion in which a change in capital structure influences all three of the previously discussed dimensions $\left(\mathrm{A}_{\mathrm{MI}}, \mathrm{A}_{\mathrm{MC}}\right.$ and $\left.\mathrm{V}_{\mathrm{C}}\right)$.

Now consider the case of O.M. Scott. We contend that the LBO's impact on value creation is best captured by the following inequality.

$$
V_{C}{ }^{C \& D}-\left(A_{M C}{ }^{C \& D}+A_{M I}{ }^{C \& D}\right)>V_{C}{ }^{I T T}-\left(A_{M C}{ }^{I T T}+A_{M I}{ }^{I T T}\right)
$$

In fact, by the time of the buyout, ITT contributed no specific cognitive value $\left(\mathrm{V}_{\mathrm{C}}^{\text {ITT }}=0\right)$, whereas cognitive cost under this owner appeared to be relatively high. The LBO contributed new cognitive value $\left(\mathrm{V}_{\mathrm{C}}^{\mathrm{C} \& \mathrm{D}}>0\right)$ while simultaneously reducing cognitive cost $\left(\mathrm{A}_{\mathrm{MC}}{ }^{\mathrm{C} \& \mathrm{D}}<\right.$ $\mathrm{A}_{\mathrm{MC}}{ }^{\text {ITT }}$ ) by granting management discretion over internal funding. This potentially created a free cash flow problem, which was however controlled by means of high leverage and contractual incentive alignment. Hence, we may reasonably suppose that, at worst, 
informational agency cost remained unchanged $\left(\mathrm{A}_{\mathrm{MI}}^{\mathrm{C} \& \mathrm{D}}=\mathrm{A}_{\mathrm{MI}}^{\mathrm{ITT}}\right)^{17}$. Consequently, the preceding inequality becomes

$$
\mathrm{V}_{\mathrm{C}}^{\mathrm{C} \& \mathrm{D}}>\mathrm{A}_{\mathrm{MC}}{ }^{\mathrm{C} \& \mathrm{D}}-\mathrm{A}_{\mathrm{MC}}^{\mathrm{ITT}}
$$

, where the right-hand side takes on a negative value.

$$
\begin{aligned}
& \mathrm{V}_{\mathrm{C}}^{\mathrm{C} \& \mathrm{D}}>-\Delta \mathrm{A}_{\mathrm{MC}} \\
& \mathrm{V}_{\mathrm{C}}^{\mathrm{C} \& \mathrm{D}}+\Delta \mathrm{A}_{\mathrm{MC}}>0
\end{aligned}
$$

Hence, the value created by the LBO was essentially the sum of C\&D's cognitive value to Scott and of a decrease in cognitive cost, which means that the most important drivers of value in this case were of a cognitive nature.

In the following two sections, we turn to a discussion of the empirical evidence in line with these assertions. This will also allow us to gain a deeper understanding of the underlying mechanisms.

\section{Controlling Shareholder and Cognitive Cost}

The O.M. Scott case actually illustrates the existence of relatively high cognitive cost under the former owner (ITT) and the way such cost may be relieved by a new dominant shareholder. In fact, with ITT closely controlling the allocation of internal funding, cognitive cost was opportunity cost due to foregone activities which were perceived by experienced incumbent management as potential sources of value.

According to Penrose (1959), the management team is a potentially valuable resource and an essential driver of a firm's development. This is so because of the distinctive skills and understanding its members develop by constantly interacting inside of a particular $\operatorname{organization}^{18}$. Following such reasoning, managers' contribution to value is essentially cognitive, because the executive team exerts significant influence on the type of productive services in which the firm's specific bundle of resources is employed. In fact, beside the 
intrinsic value of certain resources, what really makes a difference for the creation of value is management's perception of yet unexploited productive opportunities (Barney, 1986) to which resources may "optimally" be channeled. Put differently, a key element in the creation of value is "coordination control" (Langlois and Robertson, 1995), the way in which productive activities and the corresponding resources are consistently organized. Competence, however, to exert such control in a value enhancing fashion is no publicly available commodity but depends on cognitive structure and skills which evolve, at least partially, in a process of experiential and organization-specific learning. The latter is local and pathdependent, and the resulting knowledge is thus more or less difficult to transmit to outsiders to the extent that much learning of this kind is tacit in nature.

In the O.M. Scott case, the inability to communicate management's perception of specific productive opportunities to the ITT hierarchy which exerted tight coordination control over internal capital resources appears as a significant source of cognitive cost. As Baker and Wruck (1989) put it "ITT had created a control system that allowed headquarters to manage a vast number of businesses, but did not give managers the flexibility or incentive to use their specialized knowledge of the business to maximize the value of the division." (p. 177, emphasis added) Hence, there were opportunity costs due to underexploited specialized knowledge of productive opportunities. Potentially value creating investments could not be undertaken because of the regular denial of requests for capital funds (p. 184). "Seitz [Scott's CEO] had proposed that Scott enter [the] segment of the professional lawn care market for years, but ITT continually vetoed this initiative.” (p. 188)

The change in capital structure brought about by the LBO considerably reduced cognitive costs of foregone investment opportunities. Hence, "[c]apital spending increased by $23 \%$ after the buyout." (p. 165) At least two major investment projects were realized once the dominant shareholder had changed. Management's perception of development opportunities led Scott to acquire Hyponex, another lawn care company, very present in the private label market. The 
other strategic initiative was the development of the professional segment, which performed well with a growth rate of almost $40 \%$ per year (p. 188).

A close reading of the Scott case suggests that the significant decrease in cognitive cost owed to Clayton and Dubilier's recognition of the distinctive competence of the incumbent management team. Consequently, the new dominant shareholder granted greater coordination control to Scott managers concerning the way resources should be employed to serve specific productive opportunities. Consider the following. "C\&D relied much more heavily [than ITT] on managers' firm-specific knowledge, hence the incumbent management team was more valuable to the buyout firm. $C \& D$ was willing to pay managers more to reduce the risk of the managers quitting, and depriving Scott and C\&D of this valuable knowledge." (Baker and Wruck, 1989, p. 177, emphasis added)

However, to state that cognitive cost was less under C\&D than under ITT does not mean that there was no cognitive divergence at all between the Scott management and the private equity firm. In fact, Scott managers had no influence on the choice of the LBO specialist, and the latter was unilaterally imposed by ITT. Hence, at the beginning of their relationship, Scott management clearly felt some cognitive divergence with the C\&D staff. This is explicitly reported in the following quotation from Tadd Seitz.

“To be candid, they [C\&D] weren't our first choice. It wasn't a question of their acumen, we just didn't think we had the chemistry. But as we went through the controlled bid process, it was C\&D that saw the greatest value in Scott.” (Baker and Wruck, 1989, p. 173)

The use of the term "chemistry" most likely hints at the tacit dimension of mutual understanding. We think that this relative unease with the new dominant shareholder may reasonably be interpreted in terms of (at least slight differences) in mental structure. The ongoing relationship seems however to have deepened mutual understanding. In fact, quite to the contrary of their initial resentment, the Scott managers were actually encouraged to 
exploit their very own firm-specific competence. Hence, C\&D's liaison partner with Scott, Henry Timnick, stated:

“Tadd kept asking me 'Can I do this? Can I do that?' I told him, 'You can do whatever you want so long as it is consistent with Scott's overall strategy."” (Baker and Wruck, 1989, p. 183)

Thus, though not completely eliminated, cognitive cost was significantly reduced under C\&D as dominant shareholder. The reason for this is implicit in the following remark by Martin Dubilier.

"ITT challenges managers not to rock the boat, to make budget. We challenge managers to improve the business. Every company takes on the personality of its CEO.” (Baker and Wruck, 1989, p. 183)

In this context, the composition of the board of directors can be seen as one possible way of managing cognitive divergence by gaining deeper mutual understanding in a process of ongoing interaction. This is so, because the board is a potentially important interface for active communication between managers and dominant shareholders. It is quite interesting to note that C\&D's approach to board composition was explicitly not one of conflicting interests and discipline, but rather one of professional expertise.

"We will not put anyone on the board that the CEO doesn't want, but we [C\&D] have to approve them. We do not see board members as extensions of ourselves, but they are not to be cronies or local friends of the CEO. We want people with expertise that the CEO doesn't have. The CEO should choose outside directors who are strong in areas in which he is weak." (Baker and Wruck, 1989, p. 181)

Hence, it seems plausible to conclude that C\&D's experience of the LBO business helped it develop specific routines (e.g. with respect to monitoring mechanisms) which help reduce cognitive cost through time by putting people on the board who are likely to understand each other, all the while contributing to the creation of cognitive value by ways of broadening management's perception of opportunities ${ }^{19}$. Consequently, even though there was perhaps initially some cognitive cost in the relationship with the new dominant shareholder, this cost rapidly declined and was significantly lower than the pre-LBO level. 


\section{Developing Specific Capabilities of Cash Flow Management}

Reduced cognitive cost, as illustrated above, is however only one of two cognitive dimensions useful in an explanation of enhanced performance. We now turn to the second dimension identified in the Charreaux (2002) model: cognitive value.

As suggested by Baker and Wruck (1989), the strain put on cash flow by increased leverage acted as an incentive to create value. While we agree with this general conclusion, we contend that the very nature and working of those incentives - that is to say the fashion in which they precisely operate - are actually underexplored in traditional agency theory. The latter's explanation is essentially in terms of incentives for choosing exclusively positive NPV investments with fixed income streams from a pre-specified and well known set of opportunities. According to free cash flow theory, high leverage is a means of reducing incentives to over-invest. While this mechanism may be at work in some cases, we contend that it is not the most relevant for understanding O.M. Scott's substantially increased operating performance. Here, incentives for value creation actually took on a different form which has so far received less attention from the financial community. In fact, we find that in the Scott LBO, high leverage acted as a stimulus (or incentive) for learning, very much in line with Winter's (2000) characterization of the development of organizational capabilities as a satisficing search process. According to the latter analysis, overt learning to improve organizational capabilities takes place when there is a perceived gap between present capabilities and aspiration level. The intensive learning effort will most likely come to an end once the aspiration level is attained, which means that there is satisfaction with actual performance. Later on, satisficing search and related learning are possibly re-ignited when the aspiration level is shifted upwards.

In the case of O.M. Scott, it appears that high leverage, by putting strain on cash flow, lead to an upward shift in management's aspiration level with respect to capabilities related to the 
generation of internal funding. Thus stimulating a specific learning process should consequently be considered as a significant driver of Scott's enhanced operating performance. In this context, leverage acted as an incentive, not so much by preventing waste of free cash flow, but rather by shifting upwards aspiration levels, thus stimulating search for more efficient routines of cash management.

In order to improve methods to gain better access to internal funding, Scott actually created a "working capital task force", headed by John Wall, assistant treasurer. This working group "was charged with reducing working capital requirements by $42 \%$, or $\$ 25$ million, in two years." (Baker and Wruck, 1989, p. 184) Note that this is a clear indication of a shift in aspiration levels. The result of such a shift is overt learning, as can be seen from the following account by Baker and Wruck (1989, p. 184): “The task force helped Scott managers learn to manage cash balances, production, inventories, receivables, payables, and employment levels more effectively." (emphasis added) Consider also the following statement by John Wall, describing the way in which Scott tackled the challenge of controlling cash in order to meet debt service requirements.

"In the first six months after the LBO we had to bring in a state-of-the-art cash management system for a business of this size. We shopped a lot of treasury management systems and had almost given up on finding a system that would simply let us manage our cash. We didn't need a system that would keep track of our investment portfolios because we had \$200 million borrowed. Finally, we found a product we could use. Under the LBO cash forecasting has become critical. I mean cash forecasting in the intermediate and long range. I don't mean forecasting what is going to hit the banks in the next two or three days. We could always do that, but now we track our cash flows on a weekly basis and we do modeling on balance sheets, which allows us to do cash forecasting a year out." (Baker and Wruck, 1989, p. 185, emphasis added) 
This account sheds some light on the temporal dimension of the search process and related learning. Intensive search stopped when the first satisfactory solution was found. This is clearly satisficing behavior ${ }^{20}$.

In this process, $C \& D$ gave some advice. More importantly, the private equity firm had a decisive influence on aspiration levels ${ }^{21}$ and thus played a significant cognitive role. We interpret this as a manifestation of one particular mechanism by which a dominant shareholder may create cognitive value consistent with the model contained in Charreaux (2002). The following figure summarizes the underlying mechanisms.

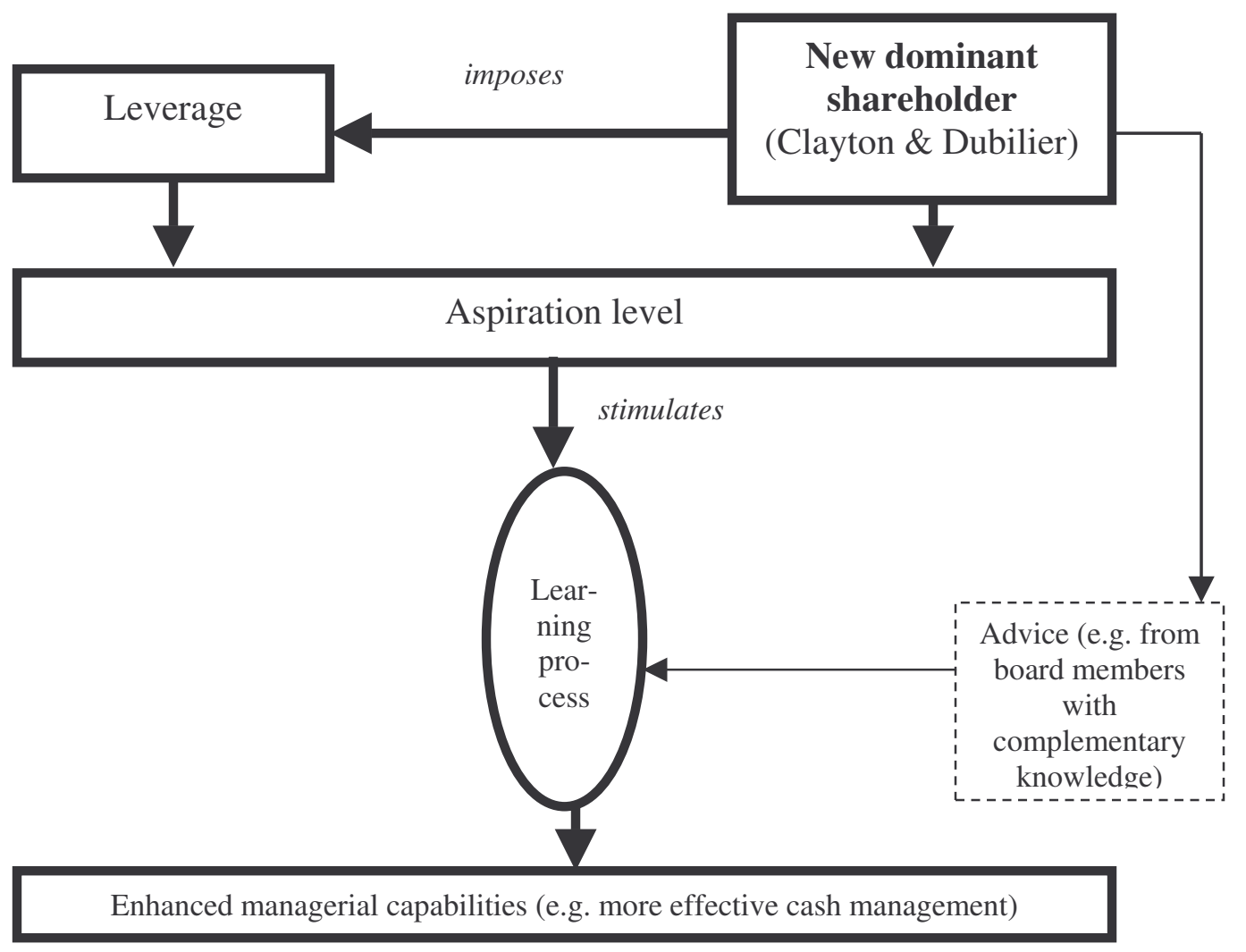

Figure I Mechanisms underlying cognitive value creation at O.M. Scott 


\section{Conclusion}

A look on the curricula of the finance courses taught in several American business schools shows that the Baker and Wruck (1989) paper has become a widely utilized classroom classic to illustrate the workings of basic agency mechanisms ${ }^{22}$. While recent scandals such as Enron, Worldcom, and others illustrate the potential ongoing relevance of many arguments rooted in traditional agency theory, we contend that its applicability critically hinges on the presence of some typical characteristics of the managerial firm, especially with respect to capital structure. Where those characteristics are absent and shareholders are not widely dispersed, other factors than informational managerial agency costs are potentially more relevant in explaining performance changes. Indeed, in the present contribution we show that reduced agency costs in the traditional sense are far from being the most plausible explanation of O.M. Scott's enhanced post-LBO operating performance. The case actually contains some very rich empirical material which is appealing to research integrating concepts from the fields of finance and strategy by considering not only financial discipline but also cognition and organizational capabilities. Following this line of reasoning, the evidence on O.M. Scott may plausibly be interpreted in terms of reduced cognitive cost and increased cognitive value brought about by changing the specific identity of the dominant shareholder. We actually find that, by granting greater coordination control over internal funding to incumbent management, Scott's new dominant shareholder (C\&D) considerably reduced cognitive cost in the form of foregone investment opportunities specifically identified as such by management's idiosyncratic expertise. In addition, the new shareholder contributed special cognitive value by igniting and influencing a search and learning process for enhanced managerial capabilities.

Without rejecting the major findings of PAT, we think that future research in corporate finance and governance has much to gain from efforts aiming at establishing more integrated 
models which are open to the cognitive and resource based perspective. While mainstream approaches to capital structure issues are much concerned with the spoliation of owners and incentives to refrain from sub-optimal behavior within a range of given alternatives, the resource based view more closely focuses on the distinct contribution of a specific bundle of idiosyncratic resources to creating value as a response to endogenously constructed opportunities. Hence, the two approaches appear to be complementary, and the presence, in a real-world case, of elements from one or the other is most likely a matter of degree. The fundamental importance of aspects related to cognition and competence has not gone unrecognized by the most active promoters of agency theory themselves. In fact, the more recent developments in this field of research explicitly make room for issues of learning in an effort to create long-run value (Jensen, 2000; Wruck and Jensen, 1994). Our own paper should thus be understood as one tentative contribution to flesh out this basic insight by delving into the underlying cognitive mechanisms.

\section{References}

Alchian, A. (1950) 'Uncertainty, Evolution, and Economic Theory', Journal of Political Economy 58 (3): 211-221.

Alchian, A. and Demsetz, H. (1972) 'Production, Information Costs, and Economic Organization', American Economic Review 62 (5): 777-795.

Baker, G. P. and Wruck, K. H. (1989) 'Organizational Changes and Value Creation in Leveraged Buyouts: The Case of the O. M. Scott \& Sons Company', Journal of Financial Economics 25: 163-190.

Barney, J.B. (1986) 'Strategic Factor Markets: Expectations, Luck, and Business Strategy', Management Science 32 (10): 1231-1241. 
Berle, A. and Means, G. (1932) The Modern Corporation and Private Property. Harcourt: Brace \& World, reedited: New Brunswick NJ: Transaction Publishers, 1991.

Charreaux, G. (2002) 'L'actionnaire comme apporteur de ressources cognitives', Revue Française de Gestion 28 (141), November-December, Special Issue: 77-107.

Conner, K.R. and Prahalad, C.K. (1996) 'A Resource-based Theory of the Firm: Knowledge Versus Opportunism', Organization Science 7 (5), September-October: 477-501.

Demsetz, H. (1988) 'The Theory of the Firm Revisited', Journal of Law, Economics, and Organization 4 (1), Spring: 141-161.

Fransman, M. (1994) 'Information, Knowledge, Vision and Theories of the Firm', Industrial and Corporate Change 3 (3): 713-757.

Gompers, P. and Lerner, J. (2000) 'The Determinants of Corporate Venture Capital Success: Organizational Structure, Incentives, and Complementarities', in R. Morck (ed) Concentrated Corporate Ownership. Chicago: The University of Chicago Press, 17-53.

Hayek, F.A. (1952) The Sensory Order: An Inquiry into the Foundations of Theoretical Psychology. Chicago: The University of Chicago Press.

Hellmann, T. and Puri, M. (2002) 'Venture Capital and the Professionalization of Start-Up Firms: Empirical Evidence', Journal of Finance LVII (1): 169-197.

Jensen, M. (1986) 'Agency Costs of Free Cash Flow, Corporate Finance and Takeovers', American Economic Review 76 (2): 323-329.

Jensen, M. (2000) 'Value Maximization and the Corporate Objective Function', in M. Beer and N. Norhia (eds) Breaking the Code of Change. Cambridge: HBS Press.

Jensen, M. et al. (1998) 'Organizations and Markets: History and Development of the Course and the Field', in T.K. McCraw and J.L. Cruikshank (eds) The Intellectual Venture Capitalist: John H. McArthur and the Work of the Harvard Business School, 1980-1995. Cambridge: HBS Press. 
Jensen, M. and Meckling, W. (1976) 'Theory of the Firm: Managerial Behavior, Agency Costs, and Ownership Structure', Journal of Financial Economics 3: 78-133.

Jensen, M. and Meckling, W. (1992) 'Specific and General Knowledge, and Organizational Structure', in L. Werin and H. Wijkander (eds) Contract Economics. Oxford: Blackwell, $251-274$

Knight, F. H. (1921) Risk, Uncertainty, and Profit. Boston MA: Houghton Mifflin, downloadable version http://www.econlib.org.

Langlois, R. N. (1995) 'Cognition and Capabilities: Opportunities Seized and Missed in the History of the Computer Industry', Working Paper, University of Connecticut.

Langlois, R.N. and Robertson, P.L. (1995) Firms Markets and Economic Change: A Dynamic Theory of Business Institutions. London / New York: Routledge.

Modigliani, F. and Miller, M. H. (1958) 'The Cost of Capital, Corporation Finance, and the Theory of Investment', American Economic Review 48: 261-297.

Nelson, R.R. and Winter, S.G. (1982) An Evolutionary Theory of Economic Change. Cambridge: Harvard University Press.

Penrose, E. G. (1959) The Theory of the Growth of the Firm. Oxford: Blackwell.

Simon, H. (1987) 'Satisficing', in J. Eatwell, M. Millgate and P. Newman (eds) The New Palgrave: A Dictionary of Economics, Vol. 4. New York: Stockton Press, 243-245.

Stulz, R. (1990) 'Managerial Discretion and Optimal Financing Policies', Journal of Financial Economics 26: 3-27.

Teece, D. J., Pisano, G. and Shuen, A. (1997) 'Dynamic Capabilities and Strategic Management', Strategic Management Journal 18 (7): 509-533.

Tripsas, M. and Gavetti, G. (2000) 'Capabilities, Cognition, and Inertia: Evidence from Digital Imaging', Strategic Management Journal 21, October-November, Special Issue: $1147-1161$ 
Wernerfelt, B. (1984) 'A Resource-Based View of the Firm', Strategic Management Journal

5: 171-180.

Winter, S.G. (2000) 'The Satisficing Principle in Capability Learning', Strategic Management

Journal 21, October-November, Special Issue: 981-996.

Wruck, K. and Jensen, M. (1994) 'Science, Specific Knowledge, and Total Quality Management', Journal of Accounting and Economics 18: 247-287.

Zajac, E. J. and Olsen, C. P. (1993) 'From Transaction Cost to Transactional Value Analysis:

Implications for the Study of Interorganizational Strategies', Journal of Management

Studies 30 (1), January: 131-145.

Zingales, L. (2000) 'In Search of New Foundations', Journal of Finance 55 (4), August:

$1623-1653$.

\section{Notes}

\footnotetext{
1 There may be information asymmetry, but this can in principle be relieved by proper, albeit costly, communication. That is, in traditional agency theory, information appears as unequally distributed but objective data. In this context, proper understanding of accessible information is not a problem, since subjective bias in perceiving objective data is absent. At worst, information is incomplete, but its meaning is independent from the receiver's mental structure. Hence, knowledge is implicitly assumed to be homogenous and not a matter of a firm's idiosyncratic bundle of (cognitive) resources. Referring to Fransman's (1998) distinction between information and knowledge, it can thus be stated that mainstream finance allows for information asymmetry while assuming potential knowledge asymmetry away. In fact, although Jensen and Meckling (1992) make extensive use of the term "knowledge", they fail to draw a clear-cut distinction between the concepts of knowledge, information and data, often using them interchangeably. Consequently, in the Jensen and Meckling (1992) framework, the transfer of even specific knowledge is never technically impossible, although it might come at prohibitive costs. Thus, such an approach neglects the highly path dependent nature characteristic of the creation of certain specific competencies.

${ }^{2}$ In fact, for large amounts of cash flow to qualify as "free cash flow" (Jensen, 1986), they must exceed the capital needs of all available positive NPV (net present value) projects. The relevance of the free cash flow hypothesis is thus conditioned on the absence of a firm-specific capability to endogenously create genuinely new opportunities for investment. If such possibilities of inventing opportunities exist, the explanatory power of the free cash flow model is considerably reduced. In fact, in that case, the access to high amounts of cash flow may actually be value enhancing. This is especially true in situations where the understanding of the investment project's value creation potential is tacit and hard to communicate to external investors (Barney, 1986).

${ }^{3}$ We borrow this term from Langlois and Robertson (1995). The latter draw a conceptual distinction between "coordination control" pertaining to the organization of productive services and "ownership control" concerning the redistribution of income streams.

${ }^{4}$ We subscribe to Tripsas and Gavetti's (2000) view that cognition and capabilities are two distinct but interacting concepts, in the sense that management's mental structures (mangerial cognition) may have a framing effect on the direction of search for new routine-like organizational capabilities. On the other hand, evolving capabilities which are to a substantial degree the result of much experiential and tacit learning also influence cognition in an ongoing dynamic process of interaction. As mental structures undergo changes, e.g. in the form of changed aspiration levels (Winter, 2000), management has an incentive to engage in learning of more
} 
sophisticated capabilities. Hence, we shall argue that the contractual arrangements observed in the O.M. Scott LBO, by putting strain on cash flow, have elevated the aspiration level with respect to the effectiveness of methods used to generate internal funding, thus stimulating the learning of new cash-flow-management skills. As a matter of consequence, it appears that an LBO specialist (Clayton \& Dubilier in the Scott case) may play a distinctive cognitive role. Our reinterpretation of the case will show that this cognitive role especially concerns the fixing of financial aspiration levels, the major orientations with respect to product market strategy being largely left to the incumbent management's unique expertise and competence.

${ }^{5}$ The remaining shareholders were debtholders (20.6\%), Scott management and employees (17.5\%), and Joseph Flannery $(0.4 \%)$, a board member.

6 "[...] it was C\&D that saw the greatest value in Scott." (Tadd Seitz, president of Scott, quoted in Baker and Wruck, 1989, p. 173)

7 Mainstream financial models' focus on the managerial firm is very explicit in Stulz (1990). Consider the following. "I analyze financing policies in a firm owned by atomistic shareholders who observe neither cash flows nor management's investment decisions." (p. 3, emphasis added) This suggests that the highest potential for agency costs in the traditional sense is typically attained when the cost of communicating specific information to shareholders is prohibitive. In that case "shareholders never believe management's assertion that cash flow is too low [...]" (ibid, p. 4, emphasis added) This may especially be the case when shareholders are widely dispersed and do not share the same understanding of the economic context. Consequently, the problem is attenuated in a case where there are only few dominant shareholders. In such a setting, the costs of communicating with and of convincing investors are significantly reduced, as is perfectly illustrated by the case of O.M. Scott. "[...] if lenders can be convinced that a particular default was not the result of a financial problem, or that a new project prohibited by the covenants would increase firm value, they have an incentive to waive the default because it increases the value of their claim. [Recall that lenders also have a $20.6 \%$ stake in equity.] In fact, despite the covenant that prohibits mergers and the acquisition of assets, Scott's lenders have recently agreed to allow Scott to acquire Hyponex [..] for \$ 111 million." (Baker and Wruck, 1989, p. 172, emphasis added) Hence, traditional problems of agency tend to be less salient when the number of investors is small and when investors are capable of understanding management's arguments.

${ }^{8}$ That is to say stemming from conflict due to objectively diverging interests. Note that this approach only holds in a world where knowledge about the set of all possible ways to create value is universal, though information about the execution of specific activities within this set is asymmetrically distributed. Hence, in mainstream explanations of capital structure there is risk but not uncertainty (Knight, 1921).

${ }^{9}$ Rather than the reduction of agency costs by taking private a widely held firm, the issue raised in the O.M. Scott case really is one of understanding the rationale behind replacing one category of (dominant) shareholder by another.

${ }^{10}$ Demsetz (1988, p. 148), among others, attracted attention to this unequal treatment of knowledge about productive opportunities and information about a manager's opportunities for shirking in traditional theories of the firm. "Although information is treated as being costly for transaction or management control purposes, it is implicitly presumed to be free for production purposes. What one firm can produce, another can produce equally well $[\ldots] "$

${ }^{11}$ The term actually employed by Demsetz (1988) is "management cost", but this term is comprehensive of agency costs in a traditional sense, which result from the management's opportunity to engage in shirking under conditions of asymmetric information and inadequate incentive alignment.

${ }^{12}$ Such efforts receive increasing support from scholars in the field of corporate finance (e.g. Zingales, 2000).

${ }^{13}$ Conner and Prahalad (1996) also identified cognitive differences between actors as one potential source of "friction". The latter term may reasonably be interpreted in terms of (cognitive) cost. Consider the following excerpt: "[...] truthful individuals honestly may disagree about the best present and future course of action for their business activities. Or, the parties may possess different mindsets generally. Discord fundamentally derives from personal knowledge that cannot be communicated fully to others at the time of the disagreement." (p. 483, emphasis added)

${ }^{14}$ With respect to the creation of new opportunities, consider the discussion of Hayek's (1952) theory of human cognition contained in Langlois (1995, p. 6): "The [mental] map is in effect a complex modular construction set that allows the organism to generate novelty through recombination." (emphasis added)

15 This appeared to be the case of O.M.Scott being controlled by ITT, where ITT's exclusive control over internal funding frustrated management's efforts in pursuing the best suited development policy.

16 The recent empirical literature on venture capital finance (Gompers and Lerner, 2000; Hellmann and Puri, 2002) provides indirect evidence on the specific cognitive contribution of certain categories of shareholders.

${ }^{17}$ However, if we follow Baker and Wruck's (1989) mainstream interpretation of the case, $A_{M I}$ C\&D should actually be (at least slightly) inferior to $\mathrm{A}_{\mathrm{MI}}^{\text {ITT }}$. While that may be so, we shall demonstrate in the following sections that this alone is insufficient to explain the considerable increase in operating performance.

${ }^{18}$ Also recall our earlier discussion of Demsetz (1988). 
19 "We have tried a number of board compositions and we found this to be the most effective. [...] Outsiders fortify the growth opportunities of the firm." (Martin Dubilier quoted in Baker and Wruck, 1989, p. 182, emphasis added) Note that the emphasized terms hint at a process of experiential learning which seems to be characteristic of the development of C\&D's own managerial capabilities.

${ }^{20}$ In fact, "optimizing", as opposed to "satisficing" (Simon, 1987), would have implied a thorough analysis of all existing cash management systems which has clearly not been done.

${ }^{21}$ Consider the following excerpt from Baker and Wruck (1989): "In conversations with managers and C\&D partners it became clear that $\mathrm{C} \& \mathrm{D}$ set higher standards for management performance than ITT. Increasing the minimum level of acceptable performance forces managers to work harder after the buyout or risk loosing their jobs. Indeed, managers did work harder after the buyout; there was general agreement that the management team was putting in longer working hours at the office. Several managers used the term 'more focused' to describe how their work habits had changed after the buyout." (p. 176, emphasis added) The latter sentence suggests that managers, in addition to working harder, also worked differently. That is to say, managerial working routines changed, which is a manifestation of learning. This is important because, if working harder was the whole story, traditional PAT reasoning would suffice, as leisure time can be analyzed in terms of agency costs due to the pursuit of managers' personal interest. Hence, what really makes a difference here is a qualitative change in work habits.

${ }^{22}$ E.g. in a section committed to "Governance, Corporate Finance, and Organizational Performance", Jensen et al. (1998) cite the O.M. Scott paper as an example. By introducing "a new genre of clinical papers", it is clearly perceived as a pioneering and thus major contribution to the field. 